\title{
Feminist Storytellers Imagining New Stories to Tell
}

Rosa de Nooijer and Lillian Sol Cueva

\section{INTRODUCTION}

Feminists use a variety of methodologies ${ }^{1}$ to make women's lives and experiences epistemologically, socially and politically relevant. One of these methodologies is storytelling, which allows for the inclusion of life histories and personal accounts in research, giving academics the chance to experiment with different ways of gathering and communicating data. Storytelling is a customary practice of transmitting histories, knowledges and cosmologies and has historically been done in various ways. Stories can be told through dance, drawn on rocks with different colored stones, told around a fire, written down in books, recorded in podcasts, shown

${ }^{1}$ Lillian's Research was supported by the Secretaría de Energia and the Consejo Nacional de Ciencia y Tecnología (SENER-Conacyt) through its post-graduate grant program.

R. de Nooijer · L. Sol Cueva $(\varangle)$

International Institute of Social Studies, Erasmus University Rotterdam, The Hague, The Netherlands

e-mail: solcueva@iss.nl

(C) The Author(s) 2022

W. Harcourt et al. (eds.), Feminist Methodologies,

Gender, Development and Social Change, https://doi.org/10.1007/978-3-030-82654-3_11 
in film or shared in comics where text and drawings tend to accompany each other (Pikola Estés, 2001: 31-39).

For feminist researchers, storytelling is a way to challenge dominant narratives which erase, oversimplify and universalize women's voices and experiences. It is an unconventional way to explore women's stories and to expand their possibilities as women tell their own stories in their own words (Woodiwiss et al., 2017).

It is our purpose to contribute to the discussion about the use of feminist storytelling. This chapter will take us, its writers and readers, to a dinner, inspired by the creative writing of Lillian, Rosa and other feminist authors who tell stories. It involves reading, quoting, conspiring, studying and supporting each other while summoning other feminists to do the same (Toupin \& Spideralex, 2018).

To do this we use creative writing and drawing, which help us to "speak and inquire differently, [to] provide a different set of data and voices, and [to] let go of some rigid notions of truth" (Moezzi et al., 2017: 7). For this chapter, we have chosen the devices of stories and storytelling, not just because of their scientific value but also because of their artistic, political and activist capacity to connect people through their tales. The chapter starts by guiding you through our methodological process, in which we elaborate how we first envisioned this chapter and its contents, as well as locating ourselves and sharing from where we write. Then the chapter continues in the shape of an illustrated story, in an attempt to search for different intellectual and emotional frameworks. In "Appetite for Change" we will show you around the dinner and define how we understand stories. We will also discuss feminist storytelling and its potential in research and in practice. In "Ultraviolet Woman-Bee", we will attempt to see the world we live in and how it is organized from another perspective. In the conclusion, we will finish the chapter by reflecting on the characteristics of feminist storytelling and by asking some questions to keep exploring this methodology in the future.

We hope that this chapter will inspire you to dream of bees dancing in the sky and sea turtles called by the moon; to imagine worlds in which women are as free as flying birds. Also, we hope this chapter will trigger a desire to meet with friends and find connections with strangers, to write creatively and think of other ways to do "academic work". Finally, while doing this we hope you have fun-a lot of fun - and feel excited to stay with the trouble because ¡Se va a caer, porque lo vamos a tirar! ("It is going to fall because we are going to tear it down!"). 


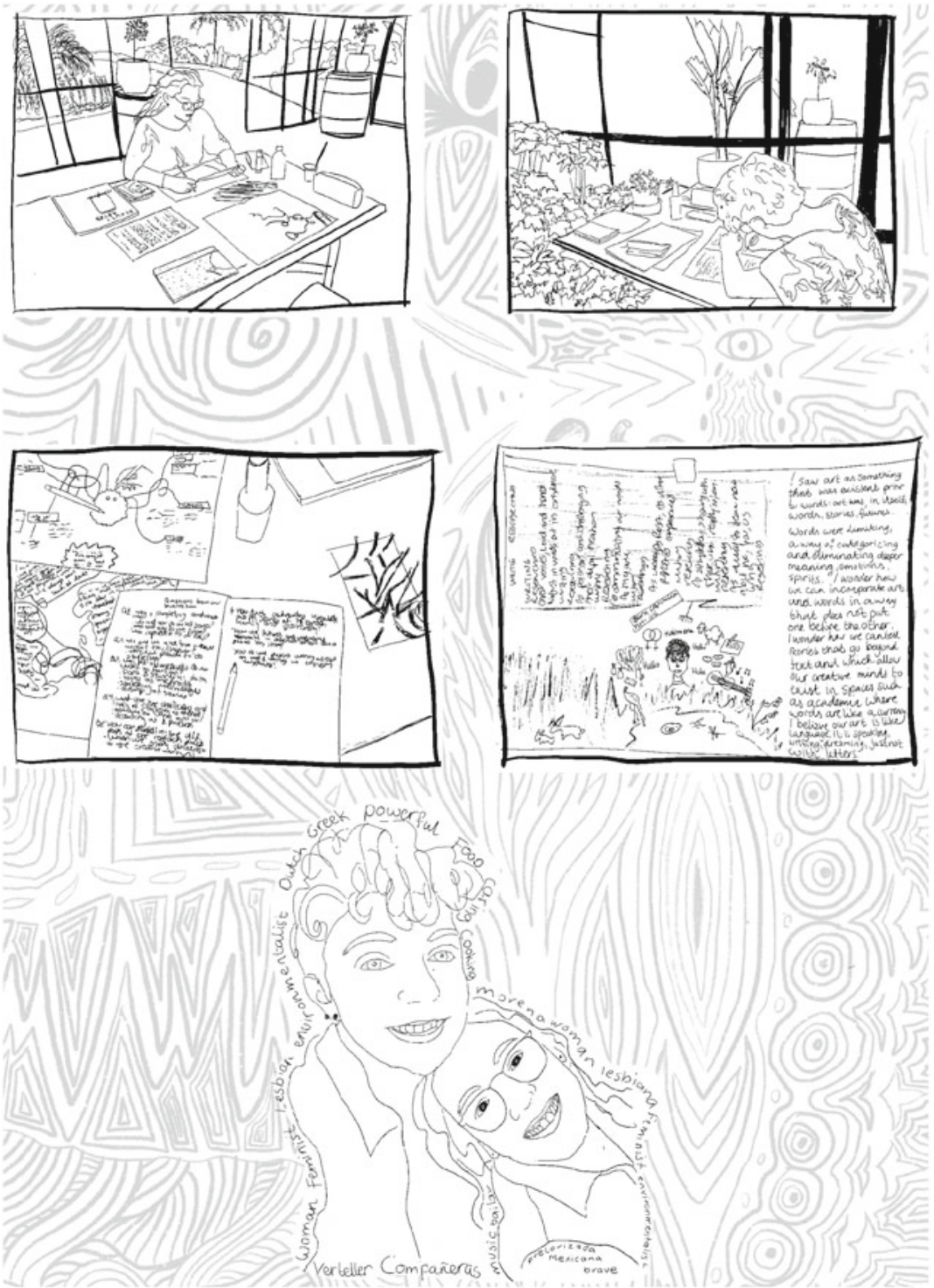




\section{Methodology: IMAgining}

Imagining a chapter together about feminist storytelling started next to a lake in Italy, in a small village called Bolsena. Here, we were part of a feminist methodologies summer school in which this book was first envisioned. We were staying at a convent surrounded by nature where we enjoyed communal spaces, told each other stories, shared food and participated in a variety of workshops. Its spirit has not changed, however, the space in which we have been creating this chapter has been quite different from where it originally sprouted. We are now in the middle of a worldwide pandemic which requires us to stay inside our homes as much as possible.

\section{The Steps}

We took different steps to agree on the content of this chapter. First, we met three times in which we came together to draw, craft, talk, be in silence and to connect our ideas. We trusted each other to organize the meetings, their location and the activities that would help us to develop our ideas and working schedule. We explored what we understand as stories and storytelling from a feminist perspective. Doing this, we documented our work and archived it as a way to inform the final writing stage of crafting this chapter.

During our meetings we agreed that we wanted to write this chapter together, to prioritize women authors' voices and to do feminist storytelling by using a combination of words and more than words. We committed to take care of each other during the working process, meaning that we shared and contributed equally, based on the activities we enjoyed the most. Also, we acknowledged that we are different in various ways, but just like nature needs biodiversity for the ecosystem to be healthy, we needed to nurture our differences to work and learn together.

We soon learned that both of us have been interested in storytelling, from a young age as a way of getting to know the world and as art form, additionally we were both using it as research methodology. Moreover, we realized that we were at different stages of our research, which allowed us to learn from each other by engaging in a dialogue about our knowledges and experiences of using storytelling as a methodology. Rosa already used 
storytelling in "The Dinner of Relations"2 and Lillian is currently creating stories with vendors at traditional marketplaces in Mexico City.

\section{The Writing and the Drawing}

This chapter is written based on creative writing, real-life dialogues between us, the authors, as well as the work of feminist thinkers, activists and artists. It is co-written and co-edited which implied close listening to one another, to voice our own opinions and to show mutual respect and understanding. We decided to use this approach inspired by Ursula K. Le Guin who said "that every story must make its own rules and obey them" (Books aren't just commodities 2018: min. 02:32-02:52). We applied her advice, not just to the content of our work but also to our collaboration while making this chapter.

Additionally, this chapter uses drawings. They are not tools to visualize what we are writing but to complement it, they are stories in and of themselves. We do not intend to attach more value to one or the other; both are equally important for communicating our thoughts and processes, for making art as well as science and for expressing creatively what words are unable to express. Illustrations create dimensions and movement, provide an atmosphere and give a face and emotions to the characters. Through this graphic form, we hope to offer a creative experience, to trigger different stimuli and therefore to open up your imagination and to attract your attention (Sandoval, 2020).

\section{The Positioning}

Finally, we write this chapter from a place which cannot be pinpointed on a map as it is informed by and connected to a variety of places, spaces, territories and lands in which we are rooted: The Netherlands, Mexico,

\footnotetext{
2 "The Dinner of Relations" is the inspiration for the dinner in this chapter. It was an imaginary setting created by Rosa for her master's research. At this dinner, farmers, loved ones, writers and academics were invited to have a dialogue about food, eating and relationality at a Dutch farm in a province called de Flevopolder. We (Lillian and Rosa) were dining there and having a conversation. For this chapter we imagined a similar setting in which we could share food and our thoughts with each other. We imagine that, as we nourish ourselves with food, our words and minds are also nourished by the company and dialogues, making eating together into something that connects us with each other and our surroundings.
} 
our bodies and our imagination. We want to occupy the specific geographies of the imaginary to have a dinner and tell stories together, while refusing the fortification of the rational ground, the certitude of already "knowing" where to go with our narratives and the practice of silencing our voices to hear the "wise" man that rules in Patriarchyland.

Similar to the impossibility to pinpoint one location from which we write, our thinking is not singular either but the result of many women's thoughts (Rowe, 2005: 15). Who we are and what we do is shaped by women who we love, respect and admire. It is also shaped by the women whose books, poetry and stories we have read, movies we have watched and art we have seen. As Aimee Carrillo Rowe (2005) argues, "[ $t]$ he meaning of self is never individual, but a shifting set of relations that we move in and out of, often without reflection" (3). In this piece in particular, we are shedding light upon our connection to the words and work of Octavia E. Butler, Brenda Navarro, Donna Haraway, Ursula K. Le Guin, Gabriela Cabezón, Gloria Anzaldua, women farmers' voices, the women in our families, our ancestras, compañeras and friends, who root us and teach us. You can see some of them sitting with us at our imaginary dinner table in one of our drawings.

We know that storytelling is not particular or exclusive to feminism, rather it is one of the many ways in which phenomena and theories about the world are described. However, we focus on the work of feminists because we find ourselves in it. It welds us together in alliances "to transform and narrate [us] who go unrecognized and whose existence is considered impossible" (Toupin \& Spideralex, 2018).

\section{Appetite for Change}

Below, we will shift to storytelling to present our own short story. We will explore what feminist storytelling means to us and illustrate what it might look like. Now, dear reader, we invite you to come with us to have dinner and to be part of the conversation. We hope this will be a space to open the scope of imagination when it comes to seeing possibilities, of actively engaging with each other in the struggle of challenging the systems we are all entangled in. Eet smakelijk! (“enjoy your meal!"). 


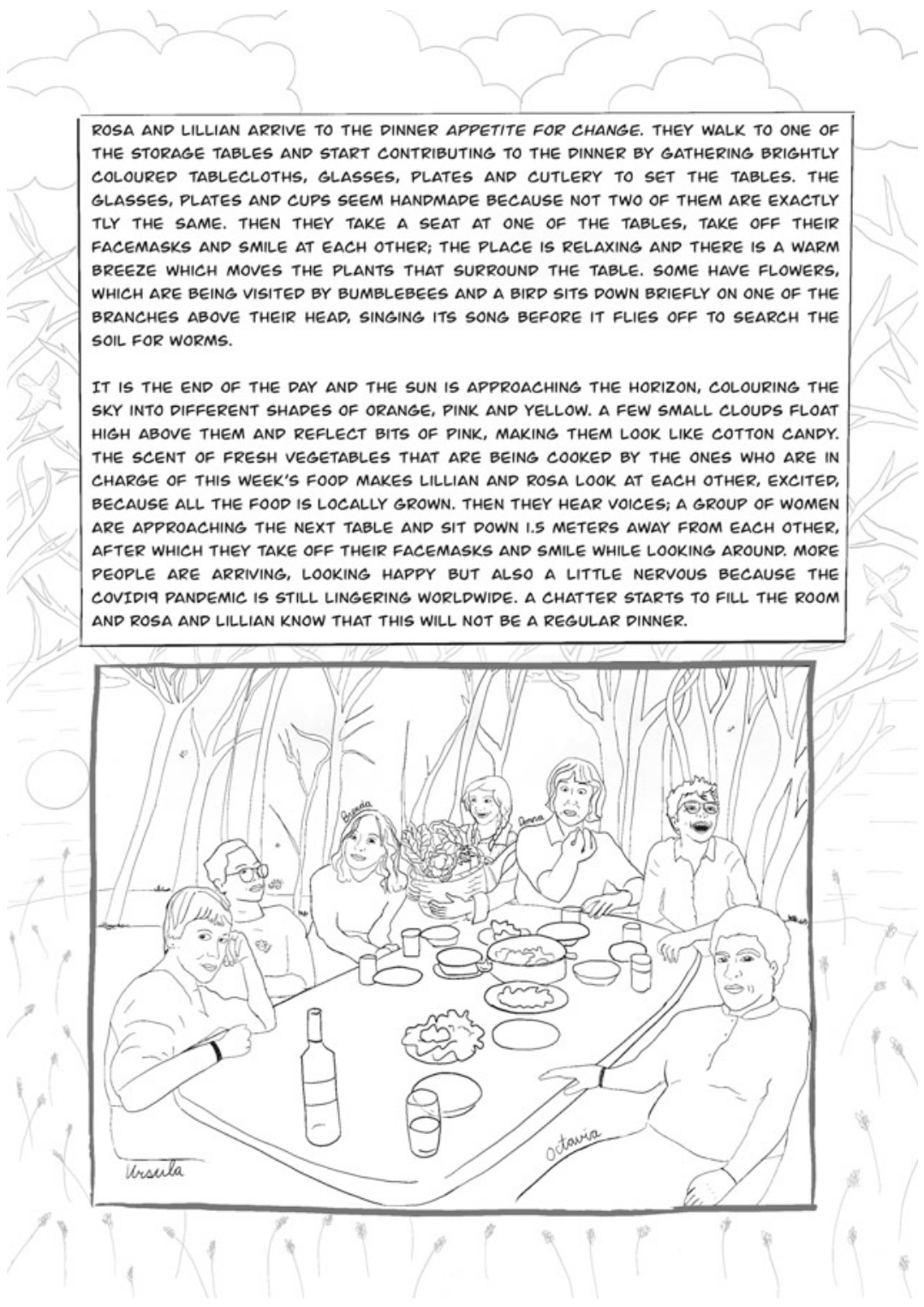




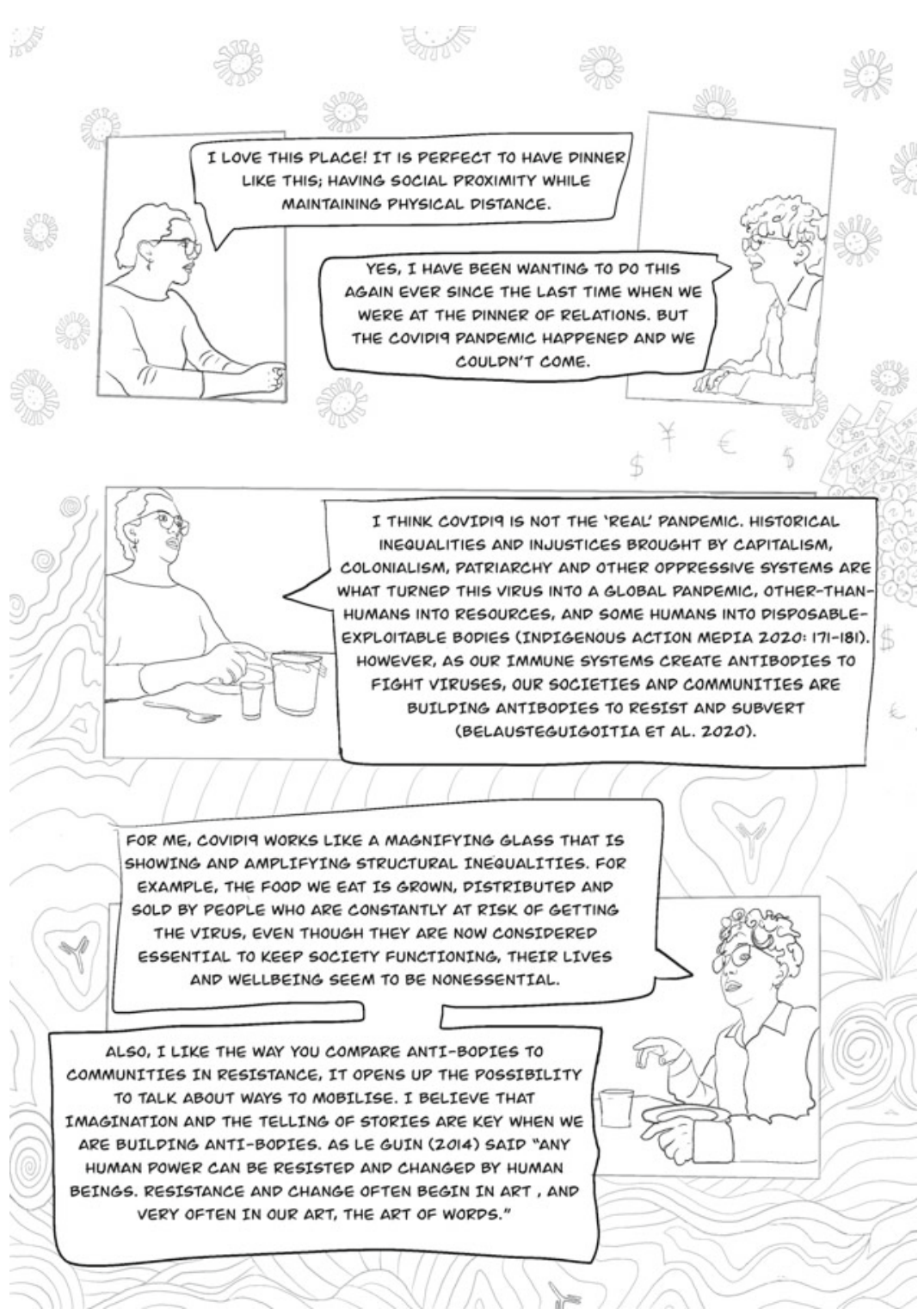




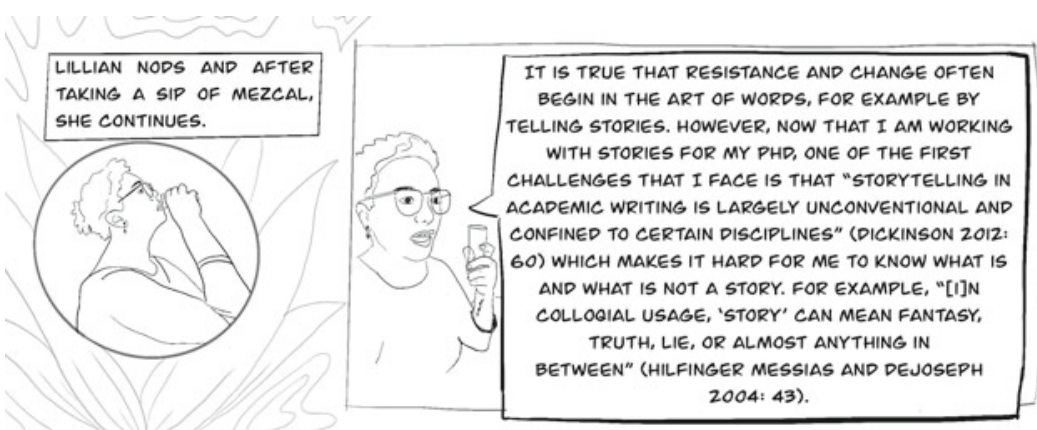

YES, TRADITIONAL ACADEMIC RESEARCH IS USUALLY POSITIONED "WITHIN EMPIRICAL, OBJECTIVE, RATIONAL, AND EUROCENTRIC FORMS OF KNOWLEDGE CONSTRUCTION" (DICKINSON 2OI2: 60). MAYBE IT WILL HELP IF YOU DEVELOP A WORKING DEFINITION OF STORY, BECAUSE HOW WE DEFINE STORY IS KEY TO THE WAY IN WHICH WE APPROACH BOTH THE COLLECTION AND INTERPRETATION OF STORIES AS DATA (HILFINGER MESSIAS AND DEJOSEPH 2004: 43),

MOEZZI ET AL. (2017) AFFIRMS THAT "[O]NE OF THE MOST COMMON DEFINITIONS OF STORY IS SOMETHING WITH A BEGINNING, A MIDDLE, AND END,

[...]. DRAWING FROM THE FIELD OF FOLKLORISTS, IN TRADITIONAL ORAL STORIES, THERE IS GENERALLY ALSO A PROTAGONIST, USUALLY A HUMAN BUT POSSIBLY ANOTHER ANIMATE ACTOR, AND OBJECT, A PRACTICE, OR AN IDEA. THEN SOMETHING HAPPENS, SUCH AS A CONFLICT BETWEEN PROTAGONISTS AND ANTAGONISTS, OR A TRANSFORMATION [...]" (2).

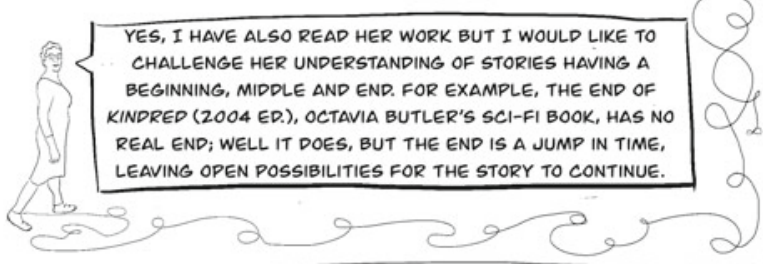

I AGREE WITH YOU THAT NOT ALL STORIES ARE LINEAR, BUT SOMETHING THAT ALL STORIES HAVE IN COMMON IS THAT THEY "EVOLVE OUT OF THE ADJECTIVES, VERBS, AND ORDERING USED TO DESCRIBE PHENOMENA AT MANY LEVELS AND IN DIFFERENT FIELDS [...]" AS MOEZZI (2017: 3) AFFIRMS.

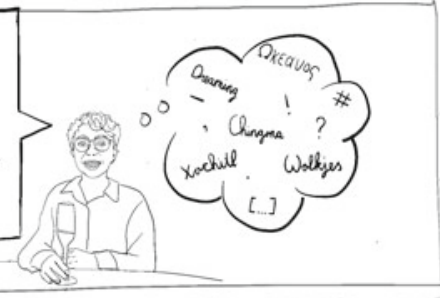




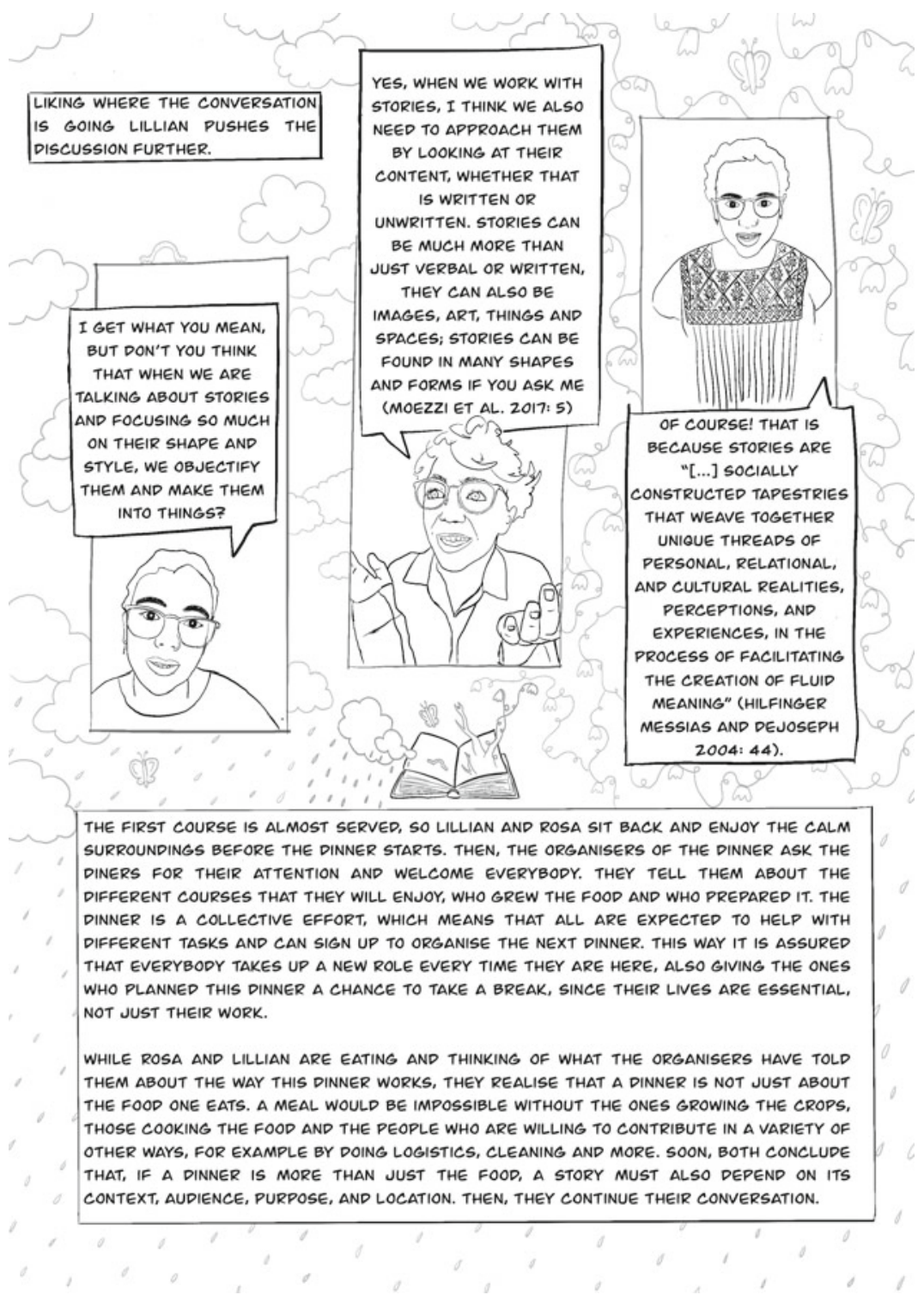




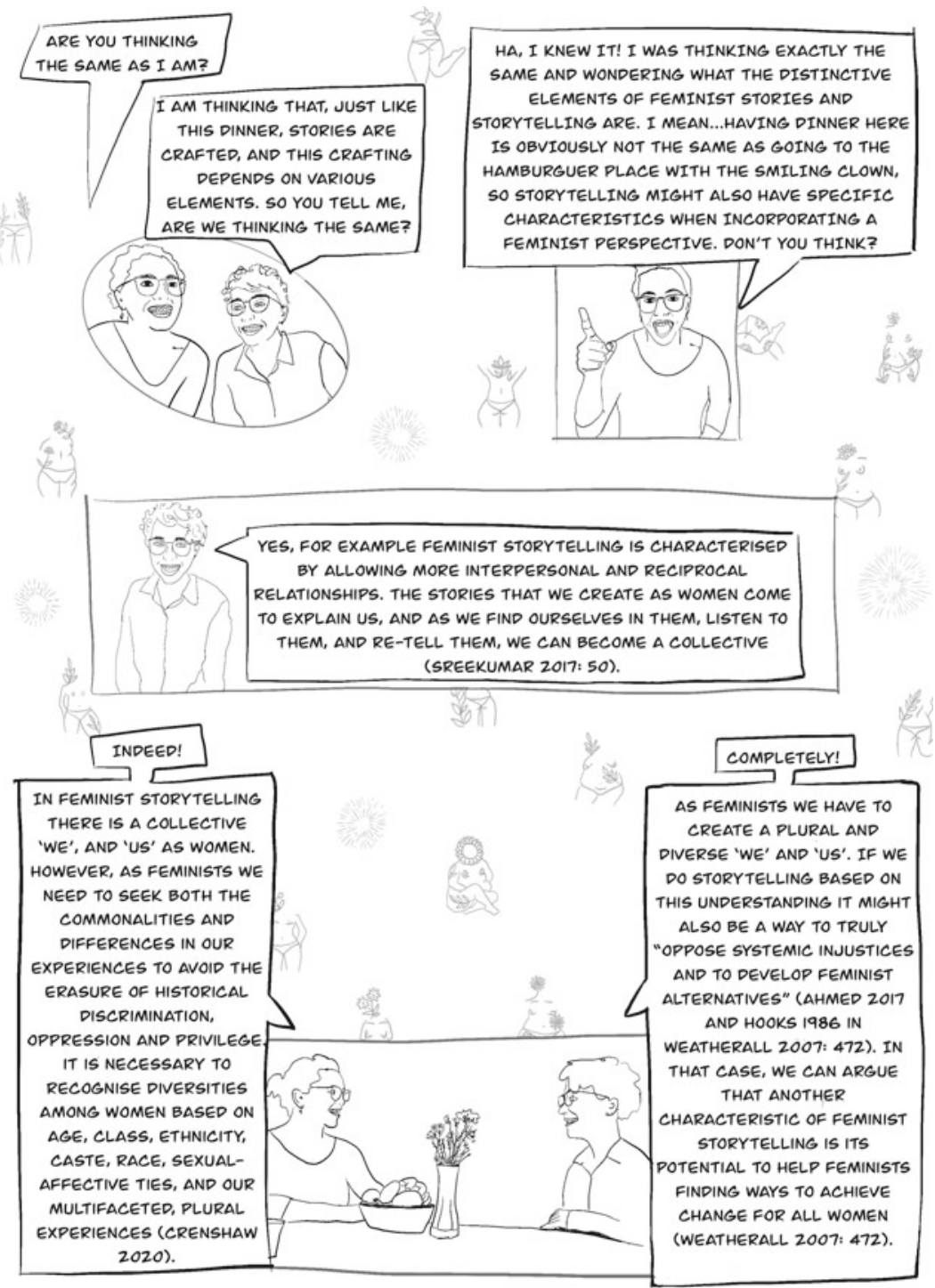

Source: Background drawing inspired by Mimteasle (Instagram), August 5th 2020 
ROSA AND LILLIAN REALISED THAT IN MANY OF THE STORIES ACCESSIBLE IN LITERATURE AND FILM, THE 'WE' AND THE 'US' ARE PORTRAYED AS TWO OPPOSITE TYPES OF WOMEN; WOMEN ARE VICTIMS OR VICTIMIZERS. THEN LILLIAN AND ROSA WONDER ABOUT THE POSSIBILITIES THAT FEMINIST STORYTELLING PRESENTS IN THIS REGARD.
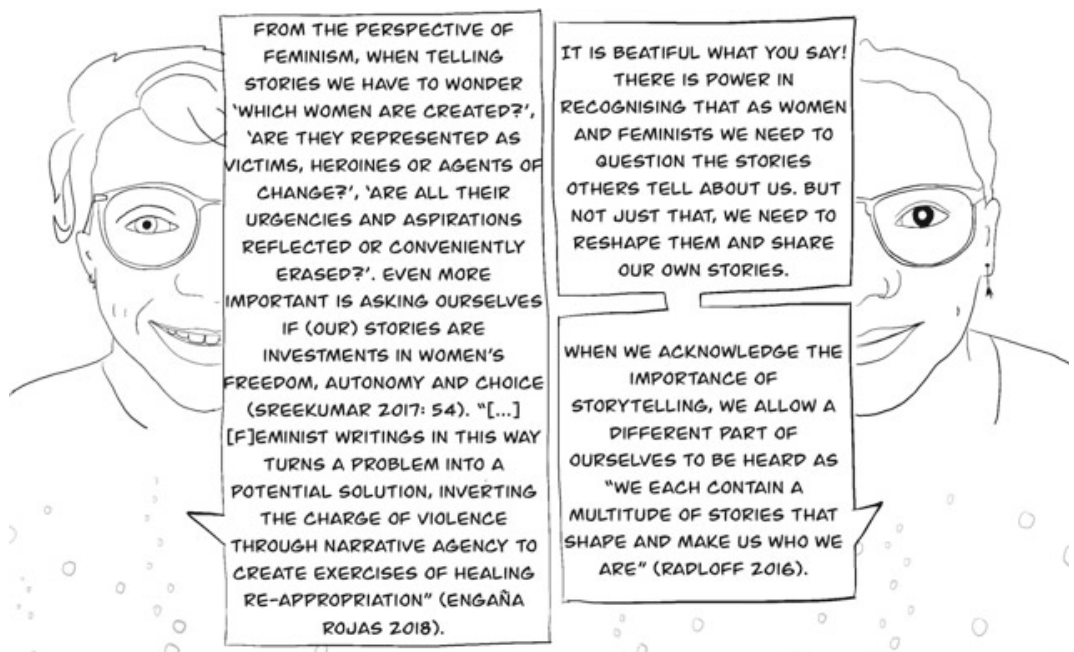

)

WHAT YOU SAID RESONATES WITH ME. WE CAN CREATE AND SHARE STORIES ABOUT OUR DREAMS OR VISIONS OF HOW WE IMAGINE A BETTER WORLD FOR OURSELVES, COMMUNITIES AND FAMILIES. WE CAN SHARE "[...] OUR STORIES OF VIOLENCE, RESISTANCE, PAIN BUT ALSO OF OVERCOMING, SURVIVING, OF LOVE, OF FRIENDSHIP" (RADLOFF 2016). THIS MAKES THE TELLING OF STORIES A POLITICAL ACT THAT ALTERS THE MEANING AND VALUE OF OUR DIVERSE EXPERIENCES.

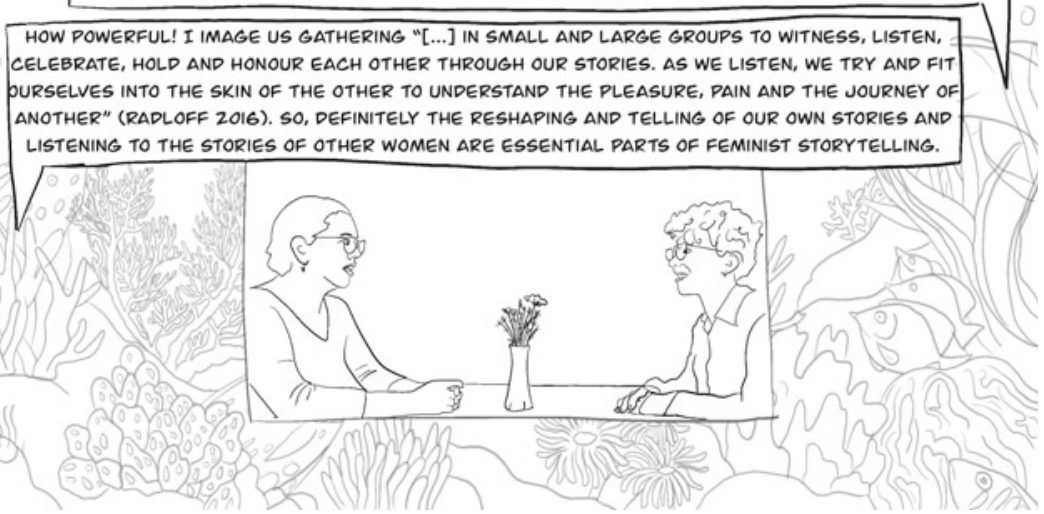




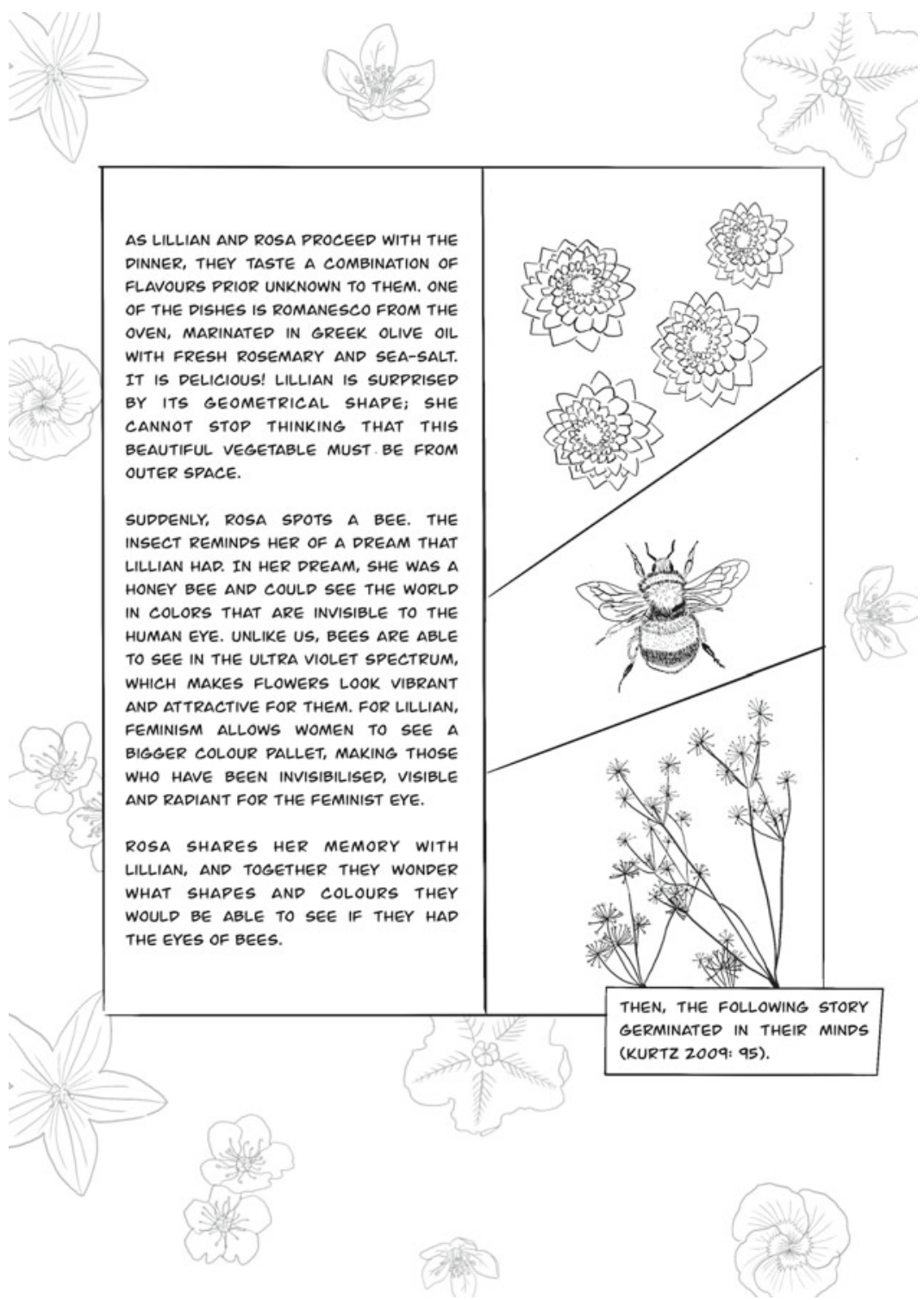




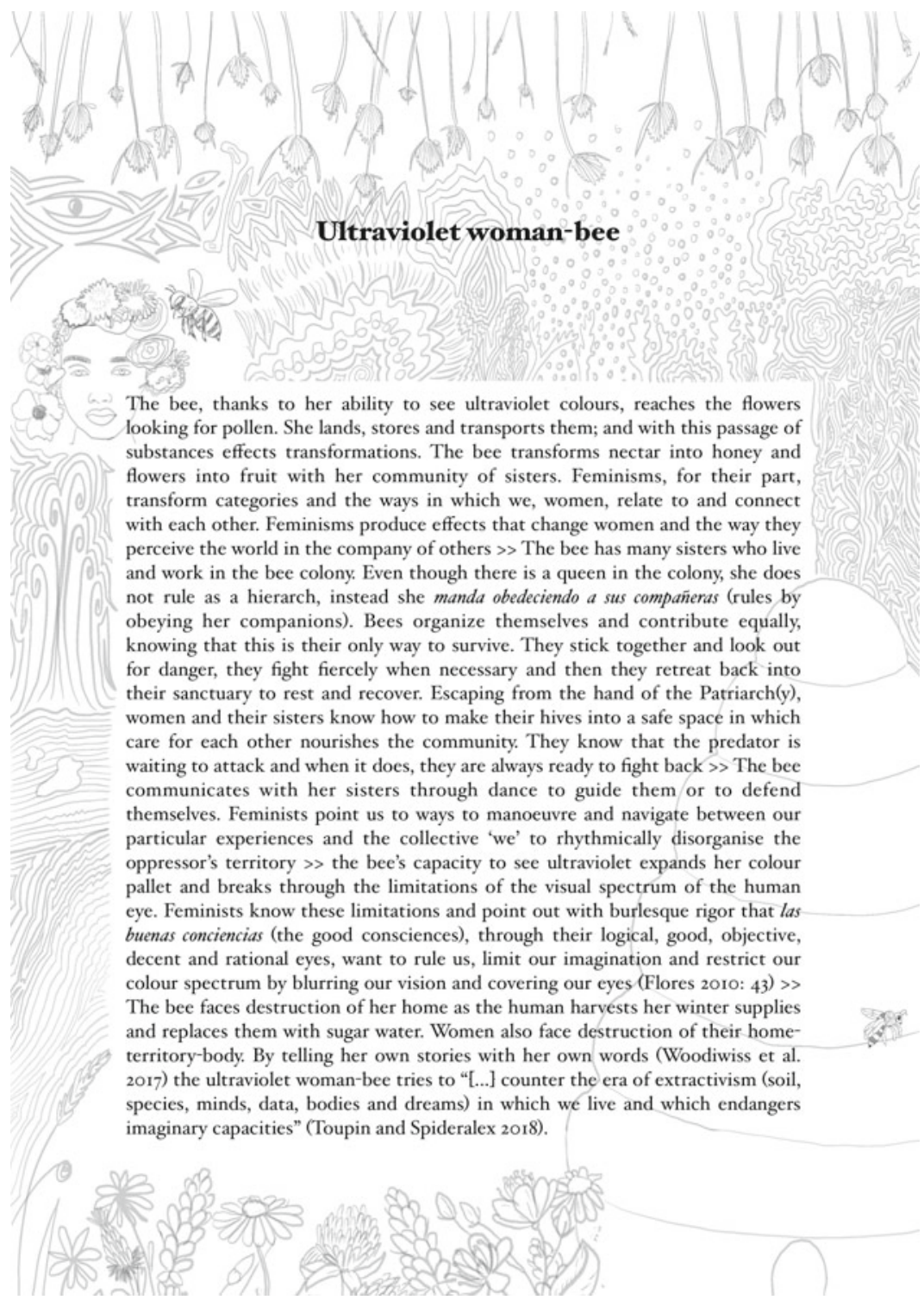




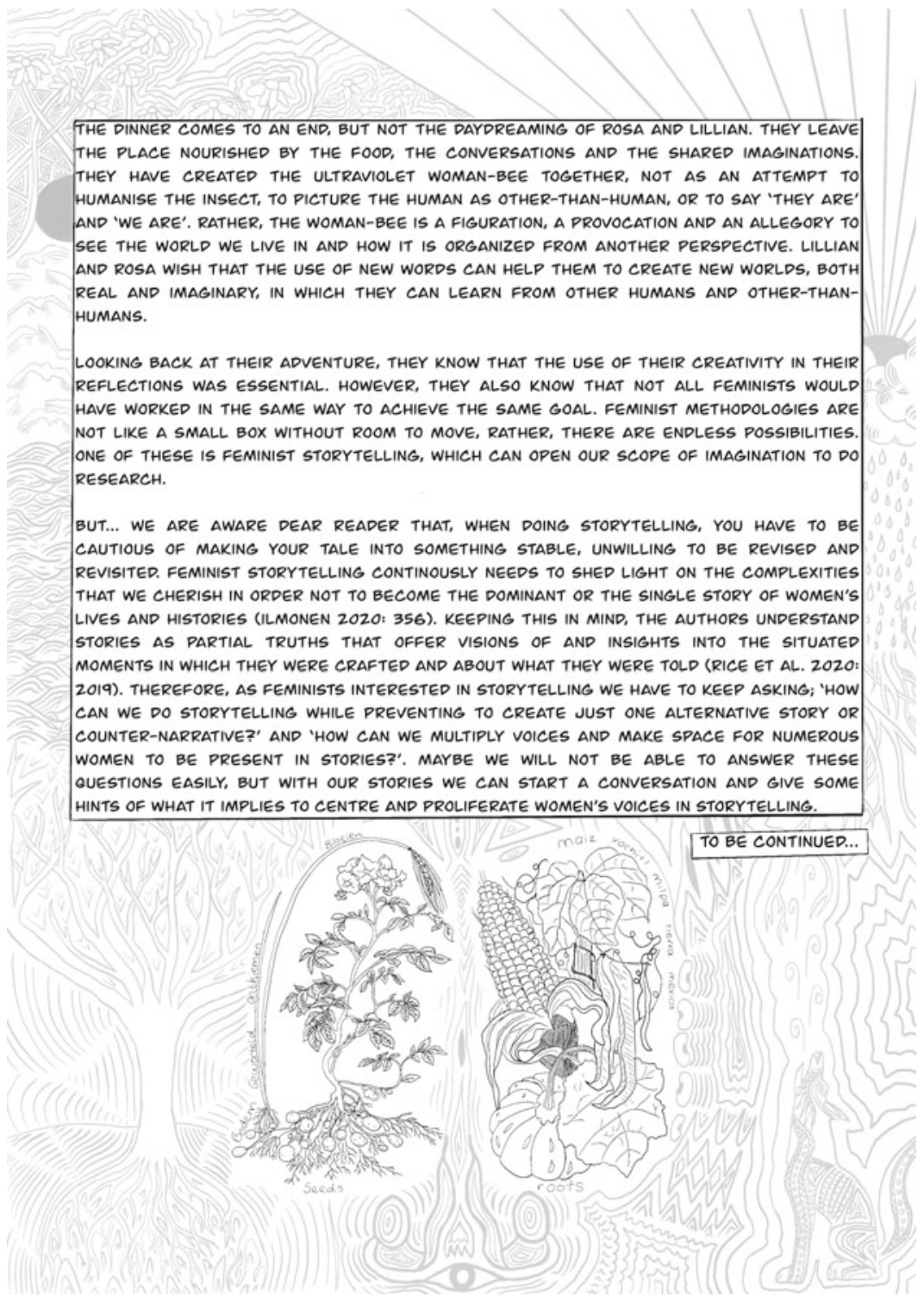




\section{CONCLUSION}

As we see how storytelling is increasingly used as a methodology in social sciences research, it is important to deepen the discussion about what storytelling entails and how it can be done. In this chapter, we have attempted to reflect on feminist storytelling by looking into what it means but more importantly by exploring how we can put this methodology into practice. By attending dinner together, being in dialogue with each other and drawing, we discussed essential elements of feminist storytelling, how it can be a useful research tool for feminists to write differently, and which other ways of listening to and sharing of stories we can use in research. We also reflected on storytelling as a way to challenge hegemonic narratives which are written based on the idea of objectivity and universality in science. More so, we pointed out that feminist storytelling might help feminists to achieve change.

We conclude that storytelling, from a feminist perspective, is necessarily an active and interactive practice that usually includes diverse women being together. We also established that an essential element while writing stories, is leaving space for the imagination, which can result in the creation of new words and therefore new worlds. We found that interweaving a plurality of voices and knowledges can allow us to write our own stories based on our own terms and rules. In this process of creation, there are endless possibilities, which we have tried to illustrate in various ways in this chapter.

Due to its experimental nature, the chapter has put new questions on the table and opened new doors to keep exploring feminist storytelling. We wonder "why visuals are important in academic writing, especially now that we are constantly surrounded by images?" and "how we can prevent the over exposition of readers to visuals?". Simultaneously, we invite researchers who want to use visual arts not to fall into the trap of treating readers as "incapable of understanding complex thoughts". Rather, we hope that they are used to enhance the reflective process and communication of research findings.

In addition to the already mentioned questions, we would like to know "how feminist storytelling can be used as a methodology when working in larger groups?" and "how feminist storytelling can be done when we are unable to meet people in person?". These questions are specifically informed by the current context in which Covid-19 is making it difficult to meet in person. 
Finally, and needless to say, this chapter has been a learning process for its authors. What you, as a reader, see in this chapter is only a snapshot of all the conversations we have had while working on it. We wholeheartedly enjoyed the process of writing/drawing this chapter together. During this work, we asked questions, imagined, drew and challenged each other. While doing all of this, we learned about the complexities of feminist storytelling as a methodology and we explored how to use visual arts in research. In our experience, feminist storytelling entails more than just the act of creating stories and writing them down, it is an interactive, reflexive and deep process that requires creativity, vulnerability and a will to maintain a critical and collaborative praxis.

\section{REFERENCES}

Belausteguigoitia, M., Ruíz, I., \& Valencia, G. (2020). Fanzine: Cuerpos y anticuerpos. Maniobras y otros contagios en tiempos de pandemia. Facultad de Filosofía y Letras, Instituto de Investigaciones Estéticas y Programa Universitario de los Derechos Humanos-Universidad Nacional Autónoma de México. Retrieved August 7, 2020, from https://t.co/2vJUS9PKs5?amp=1.

Butler, O. E. (2004). Kindred. Beacon Press.

Crenshaw, K. (2020). Intersectionality matters!. [podcast] 24. Storytelling while black and female: Conjuring beautiful experiments in past and future worlds. Retrieved August 16, 2020, from https://soundcloud.com/intersectionalitymatters/24-storytelling-while-black-and-female-conjuring-beautiful-experi ments-in-past-and-future-worlds.

Dickinson, E. (2012). Addressing environmental racism through storytelling: Toward an environmental justice narrative framework. Communication, Culture and Critique, 5(1), 57-74. https://doi-org.eur.idm.oclc.org/10. $1111 /$ j.1753-9137.2012.01119.x.

Hilfinger Messias, D., \& DeJoseph, J. F. (2004). Feminist narrative interpretations: Challenges, tensions and opportunities for nurse researches. Aquichan, 4(1), 40-49. Retrieved August 21, 2020, from http://www.scielo.org.co/sci elo.php?script=sci_arttext\&pid=S1657-59972004000100006.

Egaña Rojas, L. (2018). Suturar los espejos rotos de lo imposible (Sutured Broken Mirrors of the Impossible). Ada: A Journal of Gender, New Media, and Technology, 13. Retrieved August 26, 2020, from https://adanewmedia. org/2018/05/issuel3-rojas-engl/.

Flores, V. (2010). Deslenguada. Desbordes de una proletaria del lenguaje. Neuquén: Ají de pollo. Retrieved August 26, 2020, from https://www.bib liotecafragmentada.org/wp-content/uploads/2014/04/flores-valeria-deslen guada.pdf. 
Haraway, D. (2019). It matters what stories tell stories; It matters whose stories tell stories. a/b: Auto/Biography Studies, 34(3), 565-575.

Haraway, D. (2017, October 27). Making oddkin: Story telling for earthly survival. YaleUniversity. Retrieved March 3, 2021, from https://www.you tube.com/watch?v=z-iEnSztKu8.

Haraway, D. (2016). Staying with the trouble: Making kin in the Chthulucene. Duke University Press.

Haraway, D. (1997). Modest_Witness@Second_Millennium. FemaleMan (CMeets_OncoMouse ${ }^{\mathrm{TM}}$ : Feminism and technoscience. Routledge.

Ilmonen, K. (2020). Feminist storytelling and narratives of intersectionality. Signs: Journal of Women in Culture and Society, 45(2), 347-371.

Indigenous Action Media. (2020). Repensando el apocalipsis: un manifiesto Indigena Antifuturista. In La RECI. Todo lo que nos queda es (el) ahora. Textos con corazón y dignidad.

Kurtz, C. (2009). Working with stories in your community or organization. Retrieved September 18, 2020, from https://www.workingwithstories.org/ WorkingWithStoriesThirdEdition_Web.pdf.

Le Guin, U. K. (2014, November 19). Books aren't just commodities. National Book Awards. Retrieved August 23, 2020, from https://www.youtube.com/ watch?v=Et9Nf-rsALk.

Le Guin, U. K. (2018). In worlds of Ursula K. Le Guin [Video]. Accessed November 16, 2019. https://www.ursulakleguin.com/worlds-of-ursula-k-leguin.

Teasle, M. [@mimteasle]. (2020, August 5). New limited edition art print <3. 110 Tiny Botanical Bodies (;)... Shop link in my bio xxx [Illustration]. Retrieved September 10, 2020, from https://www.instagram.com/p/CDh YIe7Bedo/.

Moezzi, M., Janda, K. B., \& Rotmann, S. (2017). Using stories, narratives, and storytelling in energy and climate change research. Energy Research \& Social Science, 31, 1-10.

Pikola Estés, C. (Ed.). (2001). Mujeres que corren con lobos. Suma de Letras, S.L. Radloff, J. (2016). Digital Storytelling: All our stories are true and they are ours!. GenderIT: Feminist Reflection on Internet Policies. Retrieved August 25, 2020, from https://www.genderit.org/feminist-talk/digital-storytellingall-our-stories-are-true-and-they-are-ours.

Rice, C., \& Mündel, I. (2018). Storymaking as methodology: Disrupting dominant stories through multimedia storytelling. Canadian Review of Sociology., $55(2), 211-231$.

Rowe, A. C. (2005). Belonging: Toward a feminist politics of relation. NWSA Journal, 17, 15-46. 
Sandoval, V. (2020, November 20). Nido de Lectura IBBY México. [podcast]. Zanahorias, ¿Maléficas?. Retrieved from https://open.spotify.com/episode/ 5WHiFVuJU7yTbnmMv3RMw3?si=2cz-Pr2yQnK7blUEmOmqCw.

Sreekumar, S. (2017). Equivocations of gender: Feminist storytelling and women's studies in the contemporary. Indian Journal of Gender Studies, 24(1), 47-68.

Toupin, S., \& Spideralex. (2018). Radical feminist storytelling and speculative fiction: Creating new worlds by re-imagining hacking. Ada: A Journal of Gender, New Media, and Technology, 13. Retrieved August 25, 2020, from https://adanewmedia.org/2018/05/issuel3-toupin-spideralex/.

Weatherall, R. (2020). Even when those struggles are not our own: Storytelling and solidarity in a feminist social justice organization. Gender, Work \& Organization, 27(4), 471-486. https://doi.org/10.1111/gwao.12386.

Woodiwiss, J., Smith, K., \& Lockwood, K. (2017). Feminist narrative research: opportunities and challenges Palgrave Macmillan. https://doi-org.eur.idm. oclc.org/10.1057/978-1-137-48568-7.

Open Access This chapter is distributed under the terms of the Creative Commons Attribution 4.0 International License (http://creativecommons.org/ licenses/by/4.0/), which permits use, duplication, adaptation, distribution and reproduction in any medium or format, as long as you give appropriate credit to the original author(s) and the source, a link is provided to the Creative Commons license and any changes made are indicated.

The images or other third party material in this chapter are included in the work's Creative Commons license, unless indicated otherwise in the credit line; if such material is not included in the work's Creative Commons license and the respective action is not permitted by statutory regulation, users will need to obtain permission from the license holder to duplicate, adapt or reproduce the material.

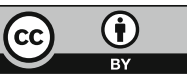

